\title{
Convergence of two controlling terms. Do we face a common future between controlling and management accounting?
}

\author{
Juraj Mišún ${ }^{1, *}$, and Ivana Mišúnová Hudáková ${ }^{2}$ \\ ${ }^{1}$ University of Economics in Bratislava, Faculty of Business Management, Department of \\ Management, Dolnozemská cesta 1/b, 85235 Bratislava, Slovak Republic \\ ${ }^{2}$ University of Economics in Bratislava, Faculty of Business Management, Department of \\ Management, Dolnozemská cesta 1/b, 85235 Bratislava, Slovak Republic
}

\begin{abstract}
Every single theory is based on some fundamental terms, which can also be used by other, unrelated theories. However, in our case, two related theories use the same basic term. "Controlling" terms are used in management (one of the main management functions) and management accounting (a management subsystem that helps managers to make qualified decisions). This semi-continental problem begun to emerge in the last years, since English has become the main language of scientists, even the coexistence of two controlling terms has lasted for almost half a century. The German controlling term needed an appropriate translation back into English. While the German-speaking authors quietly found other terms for translating, many authors from Central and Eastern Europe (CEE) mistakenly assume that English and German "controllings" are equivalents, causing an increase of confusing literature. To solve this problem, we need a clear separation of the two theories and a qualitative prognosis of possible development. In this paper, we used a relatively simple but reliable method for the prognosis, which includes five different scenarios of development. Ultimately, management or managerial accounting is the most widely used translation. Therefore, we assume that in the long term, this term will gain the major position.
\end{abstract}

\section{Introduction}

Controlling - a powerful word causing feelings of great power or helplessness. Someone is controlling something or even somebody. Although there may be no doubt, what is meant, the opposite is true. These doubts stem from different countries and languages. The word controlling is used in English, German, in many CEE languages, and in management and business economics. Schwarz argues [21, p.VI]: "science is always world science. There is no German controlling, just as there is no German physics." Yet, here we are - saying one English word and meaning two different concepts. Why is it interesting to solve this problem? The main threat is an increase of confusing literature when German knowledge is translated into English and collides with Anglo-American knowledge.

We would not have to be in the current situation at all, if the:

a) discussion between Goodwin [8] and Urwick [24] about control and controlling did not end with the relative victory of Urwick;

\footnotetext{
* Corresponding author: juraj.misun@euba.sk
} 
b) management literature would sufficiently deal with the manager-controller relationship;

c) German naming in the early seventies would be based on a sufficient examination of the use of this term;

d) German professional word "Kontrolle" gained the meaning it already has in common life.

\section{Theoretical background}

In this part, we explain the development of the word "control" in different languages, and look closely at the use of this term in German business economics and Anglo-American management. Our intention is also to determine the relationship between these terms.

\subsection{Problem with the word "control"}

When examining the issue, we immediately came to the root of the problem - the very word "control". Its meaning, its connotations, create two different directions that have caused different development with the same used term. Even in English, we cannot find a clear definition of the word and it has many meanings. There are different variations of differences, ranging from prohibiting to manipulating. According to Emmanuel et al. [6] there are two major themes in these variations a) control as domination and; b) control as regulation. However, in both, we see the power to influence the development in the way the one who controls (controlling entity) desires.

The real problem occurs actually, when we look at the word control in terms of German or French language. This issue is well described by Schwarz [21]. The word "control" has two almost opposite meanings in the German, French and English languages. The German word "Kontrolle" was borrowed from the French "contrôle" in $18^{\text {th }}$ century. However, the original French meaning "counter register for confirming the information from an original register" acquired the German meaning "Supervision, (re)examination, oversight". However, we consider Latin as the origin of "control."

A different development took place in English. Based on Goodwin's research [9], the French word was adopted into English in 1475 and later obtained the meaning of regulation, domination and direction. A similar meaning as in English was adopted in Germany in the $20^{\text {th }}$ century [20], but the history of "control" caused problems in the current use of the term controlling.

The comparatively large problem is that German literature still suggests that control is somewhat inferior and bad. Such expressions arise when comparing "Kontrolle" with "Controlling". Jung [12, Abb.78, p.1162], states in a scheme that "Kontrolle" is "backwardlooking", "identifying errors, searching for culprits", "accusing, punishing". On the other hand, the knight in shining armor "Controlling", is "forward-looking", "helping, guiding".

\subsection{Controlling in German business economics}

To bypass the limitations resulting from the German meaning of the word "Kontrolle" Albrecht Deyhle introduced at the beginning of the 1970s a new term - controlling. "Well, we got the word or the term Controller from the US. The word controlling is not as common in the US as far as I know. ... It was probably myself. I did it as a twin sister to marketing. [2, p.100]" In addition, some authors argue that the term controlling is currently virtually meaningless in English science. "Rather, it is referred to as 'management accounting' [14, p.13]."

One of the definitions states, it "means the target-related support of management tasks serving the system-based procurement of information and the information processing for the drawing up of plans, co-ordination and control; it is therefore a systematology improving the quality of decisions on each management level of the company" [19, p.12]. However, many authors point out that there is still no consistent definition. 
After studying nearly 70 German controlling publications on the issue, we found only one that describes our problem. Stoffel [22, p.9] states: "While in the Anglo-Americanspeaking world the term Controllership is used as comprehensive term for the specialization and centralization of certain tasks with the controller and the tasks of the controller are called Controller Functions and Controllership Functions respectively, the term Controlling is used in the US-American management literature quite predominant in the meaning of management process."

Another major problem is that while the meaning of the word Kontrolle has changed in the German language in the $20^{\text {th }}$ century, the most German-speaking authors do not reflect this fact in their works. In many German publications, great emphasis is placed on the claim that control is not controlling (Controlling ist nicht Kontrolle). In English-written literature, we do not find such a discussion and controlling is simply a regular exercise of control.

A special feature of German controlling development lies in the international isolation, which lies in language barriers and separation of international developments chosen by the respective scientists themselves. Many scientists published long time only in German language [7]. However, the theory is not completely isolated and we certainly do not mean the other German speaking countries.

At the beginning of the 1990s, German controlling knowledge base was relatively large. When the Iron Curtain fell, it affected research at CEE universities. Language skills of CEE scientists included mainly Russian, but also German to some extent. Only relatively few scientists could speak well in English. It was a very fertile ground for any German theory, German foreign investments were also an important factor. The relatively large area of the former Warsaw bloc means, we can call the German controlling theory a semi-continental one. Yet, controlling research has considerably transformed in German speaking countries. For long, German speaking students, professors and researchers of controlling have been rather isolated, but in the last years, it increasingly changed [20]. Now, it would be appropriate to unify the basic concepts of terms controlling and management accounting in German literature to avoid incorrect explanation and interpretation of these concepts [15].

\subsection{Controlling in management}

The term controlling is in management used for describing the management function of control, as suggested by Henri Fayol and later accepted by many American and English speaking authors. Since then, control is a solid part of the division of management into functions, and almost all management authors respect this fact. "The management textbook by Koontz and O'Donnel (Principles of Management: An Analysis of Managerial Functions, McGraw-Hill, New York, 1955) contributed to the widespread use of 'controlling'." [20, p.1] Currently, controlling is used for describing the managerial function in many bestselling management textbooks. This management function is critical for organizational success [18] and is always purposeful - regulating a system according to someone's purposes [10]. Its essence is the regulation of work of subordinates [23] and can be considered as a convergence point between accounting, business policy and management theory [4]. Yet, even without this discussion, the literature that deals with the management function of control is full of terms that are used interchangeably [3].

Many definitions in the German literature focus on the comparative aspect of control [5]. It is often understood as a comparison of two variables (e.g. is/should be, norm/fact). It is surprising, because the common German phrase "Alles unter/ausser Kontrolle" does not mean "everything in/out of comparison". Management theory clearly states, that control process ends with corrective action. "The German-language controlling literature seems to have a rather disturbed relationship to 'Kontrolle"' [20, p.47]. The use of English words in Germany and the subsequent effort to translate into English can cause great confusion.

\subsection{Relationship of the two controlling(s)}


Particularly interesting is the question of mutual position of controlling in both meanings. We can conclude there is a relatively broad consensus: although a manager should be in a higher position, a controller is not subordinated. In German literature, a controller is often described as a helmsman/navigator on a ship, while manager represents the captain.

The literature on German controlling and global management accounting is heavily concerned with the relationship between the manager and the controller. Management publications do not come close to this issue at all and mostly ignore the fact that in practice businesses already have to deal with this relationship.

\section{Aim, methodology and limitations}

The aim of this paper is to separate the two controlling theories, and to outline possible scenarios of further development due to the confusing current state. Our goal is far from identifying which theory is correct, better or should be superior to the other. However, we would like to encourage a debate about the future.

In the case of the scenarios of future development, we chose a simple and relatively fast method. From the website WHU - Otto Beisheim School of Management [25], we gathered a list of institutes, chairs, departments and professorships of German controlling in Germany, Austria (A) and Switzerland $(\mathrm{CH})$. Then, we then searched for official translations of their names into the English language.

We proceeded as follows: first, we tried to find the official site of the department in English; if the page could not be found, we were looking for an official translation within the organizational structure of the university; if this structure was not available, we looked for authors from the department in English written papers. Unfortunately, in some cases we were not successful, as many authors still publish their works exclusively in German language.

The first such survey was conducted in 2018, and this year we updated the list of departments/chairs as many of them have added their English website, or their members are publishing more in English-written publications.

Based on names, we have assigned individual chairs to individual scenarios, as their names should reflect their current and future focus. In the case of the four chairs, we have also made an in-depth analysis; since their focus has not been sufficiently clear (Chair of Business Taxation and Auditing; Chair of Finance and Control; Chair of Controlling/Performance Management; Chair of Internal Control/Internal Audit). Overall, we appointed 84 of 94 chairs to the scenarios. The remaining 10 did not have an official translation on their website or left their title in a German original, as justified earlier.

In this section, we would also like to draw attention to a certain limitation based on our position. Both authors are active in the field of management rather than the business economics, which can affect our findings. Even if we try to maximize our objectivity, we both study the management function of control. To avoid this limitation, we tried to study thoroughly the literature of the business economics field, especially in the German language.

\section{Results and discussion}

In this part, we focus on the foreseeable future. What are the possible scenarios for further development of this issue? In our opinion: a) coexistence with limitations, b) slow disappearance, c) fight for the term, d) the golden mean, and e) one future.

\subsection{Coexistence with limitations}

The first scenario expects no changes. The German/CEE authors will use the term controlling to describe the business-economics theory, the English-speaking authors the management function. Restrictions will start only when the language switches to English or the location changes to geographic CEE. However, these limitations can be eliminated by 
clearly set rules. One of these rules could be a unified translation or an explicit statement of meant meaning in the abstract of a paper. Due to compliance with the rules, there would be less confusion. Although it may currently seem useless to make any rules, it is necessary to realize that more scientists are interested in publishing in renowned journals in English. German journals will probably change their language to English to increase their global impact and increase their inclusion in prestigious scientific indexes. Examples for such rules might be publications by Luther, Jones \& Saxl [16] or Horvath [11]. On the other hand, once we have discovered this issue, we started using the term "control(-ling)" in titles of our papers.

It is very interesting to see that some German and associate chairs are even using names, which lead more to management than to the management accounting. When translating the word controlling from German into English in names of German chairs, this applies to eight of the 84 cases (table 1).

Table 1. Translations of chair's names from controlling to management control

\begin{tabular}{|l|l|l|}
\hline \multicolumn{1}{|c|}{ University } & \multicolumn{1}{|c|}{ German name } & \multicolumn{1}{c|}{ English translation } \\
\hline $\begin{array}{l}\text { ESCP Europe Business } \\
\text { School }\end{array}$ & $\begin{array}{l}\text { Lehrstuhl für Unternehmensethik } \\
\text { und Controlling }\end{array}$ & $\begin{array}{l}\text { Chair of Business Ethics and } \\
\text { Management Control }\end{array}$ \\
\hline $\begin{array}{l}\text { Georg-August-Universität } \\
\text { Göttingen }\end{array}$ & $\begin{array}{l}\text { Professur für Management und } \\
\text { Controlling }\end{array}$ & $\begin{array}{l}\text { Chair of Management and } \\
\text { Control }\end{array}$ \\
\hline $\begin{array}{l}\text { Julius-Maximilians- } \\
\text { Universität Würzburg }\end{array}$ & $\begin{array}{l}\text { Lehrstuhl für BWL, insbesondere } \\
\text { Controlling und Interne } \\
\text { Unternehmensrechnung }\end{array}$ & $\begin{array}{l}\text { Chair of Business } \\
\text { Management, Management } \\
\text { Accounting and Control }\end{array}$ \\
\hline Universität Innsbruck (A) & $\begin{array}{l}\text { Institut für Organisation und Lernen } \\
\text { - Bereich Controlling }\end{array}$ & $\begin{array}{l}\text { Department of Organisation } \\
\text { and Learning - Management } \\
\text { Control }\end{array}$ \\
\hline $\begin{array}{l}\text { Alpen-Adria Universität } \\
\text { Klagenfurt/Wien/Graz (A) }\end{array}$ & $\begin{array}{l}\text { Institut für Unternehmensführung, } \\
\text { Abteilung Controlling und } \\
\text { Strategische Unternehmensführung }\end{array}$ & $\begin{array}{l}\text { Department of Management } \\
\text { Control and Strategic } \\
\text { Management }\end{array}$ \\
\hline $\begin{array}{l}\text { Johannes Kepler } \\
\text { University Linz (A) }\end{array}$ & Institut für Controlling \& Consulting & $\begin{array}{l}\text { Institute for Management } \\
\text { Control \& Consulting }\end{array}$ \\
\hline Universität Wien (A) & Lehrstuhl für Controlling & $\begin{array}{l}\text { Department of Business } \\
\text { Administration }\end{array}$ \\
\hline $\begin{array}{l}\text { Wirtschaftsuniversität } \\
\text { Wien (A) }\end{array}$ & $\begin{array}{l}\text { Institut für Unternehmensführung, } \\
\text { Controlling und Beratung }\end{array}$ & $\begin{array}{l}\text { Institute for } \\
\text { Strategic Management and } \\
\text { Management Control }\end{array}$ \\
\hline
\end{tabular}

\subsection{Slow disappearance}

Another scenario suggests that German controlling authors will not accept the aforementioned restrictions. Many will want to continue to use the term controlling, but the next and the next generation will get used to the English terms management/managerial accounting. "Controlling" will gradually remain in management only, also because English publishing authors will still not be aware that this term is being used for something else. The conservative generation will thus have to follow the fact that the term is becoming less apparent in scientific work, and after some decades, it almost erodes. Reviewers of books and papers will require using English terms what will even more accelerate such erosion.

Of the 84 departments/chairs, we would assign $\mathbf{4 0}$ to this scenario, as they a) mostly highlight management/managerial accounting/overall accounting in the translation; $b$ ) have a clear financial focus on auditing, internal audit and internal control. In addition to the terms management/managerial accounting, we also find related terms in the names of these university departments/chairs: RWTH Aachen University, Freie Universität Berlin, Universität Bielefeld, Ruhr-Universität Bochum, Brandenburgusche Technische Universität 
Cottbus - Senftenberg, Technische Universität Darmstadt, Heinrich Heine Universität Düsseldorf, Universität Duisburg Essen, Katholische Universität Eichstätt-Ingolstadt (2), Goethe Universität Frankfurt am Main, Europa Universität Viadrina Frankfurt, JustusLiebig Universität Giessen, FernUniversität in Hagen, Technische Universität HamburgHarburg, Leibniz Universität Hannover, Friedrich-Schiller-Universität Jena (2), Technische Universität Kaiserslautern, University of Cologne, Leipzig Graduate School of Management, Johannes Gutenberg-Universität Mainz, Universität Mannheim, PhilippsUniversität Marburg, Technische Universität München, Universität der Bundeswehr München, Universität Osnabrück, Paderborn University, Universität Potsdam, Universität des Saarlandes, Eberhard Karls Universität Tübingen, Universität Innsbruck, Universität Basel (2), Universität St. Gallen (4), Universität Zürich (2).

\subsection{Fight for the term}

The German controlling theory can still become global theory from the current semicontinental one. How could this be achieved? There would be a need for a greater number of publications in English in renowned journals that would adequately distinguish controlling and management accounting. There is still a chance to make this scenario happen, since there is not an absolutely compliance in using the term controlling for describing the managerial function. Another opportunity hides the fact that not so many scientists are exclusively devoted to the management function of controlling. This leaves it as a small part of something bigger, in our case management. Authors of general management publications are unlikely to oppose too much if they have to rename one of their chapters in later editions. However, they must learn that a second controlling term even exists.

We would assign ten departments/chairs to this scenario. The reason is simple: they translate the German term controlling into English as controlling (Table 2).

Table 2. Translations of chair's names from controlling to controlling

\begin{tabular}{|l|l|l|}
\hline \multicolumn{1}{|c|}{ University } & \multicolumn{1}{|c|}{ German name } & \multicolumn{1}{c|}{ English translation } \\
\hline $\begin{array}{l}\text { Universität } \\
\text { Augsburg }\end{array}$ & $\begin{array}{l}\text { Lehrstuhl für Wirtschaftsprüfung und } \\
\text { Controlling }\end{array}$ & $\begin{array}{l}\text { Chair of Accounting \& } \\
\text { Controlling }\end{array}$ \\
\hline $\begin{array}{l}\text { Universität } \\
\text { Augsburg }\end{array}$ & $\begin{array}{l}\text { Lehrstuhl für Betriebswirtschaftslehre } \\
\text { mit Schwerpunkt Controlling }\end{array}$ & Chair of Controlling \\
\hline $\begin{array}{l}\text { Technische } \\
\text { Universität Berlin }\end{array}$ & $\begin{array}{l}\text { Institut für Betriebswirtschaftslehre, } \\
\text { Fachgebiet Unternehmensrechnung und } \\
\text { Controlling }\end{array}$ & $\begin{array}{l}\text { Institute of Business } \\
\text { Administration Controlling and } \\
\text { Accounting }\end{array}$ \\
\hline $\begin{array}{l}\text { Friedrich-Alexander } \\
\text { Universität } \\
\text { Erlangen-Nürnberg }\end{array}$ & $\begin{array}{l}\text { Das Institut für Finance, Auditing, } \\
\text { Controlling, Taxation }\end{array}$ & $\begin{array}{l}\text { Institute of Finance, Auditing, } \\
\text { Controlling, Taxation }\end{array}$ \\
\hline $\begin{array}{l}\text { Universität } \\
\text { Hohenheim }\end{array}$ & Lehrstuhl Controlling & $\begin{array}{l}\text { Finance, Controlling \& } \\
\text { Entrepreneurship }\end{array}$ \\
\hline $\begin{array}{l}\text { Universität } \\
\text { Regensburg }\end{array}$ & Lehrstuhl für Controlling und Logistik \\
\hline $\begin{array}{l}\text { Universität des } \\
\text { Saarlandes }\end{array}$ & $\begin{array}{l}\text { Lehrstuhl für Betriebswirtschaftslehre, } \\
\text { insbesondere Controlling }\end{array}$ & $\begin{array}{l}\text { Chair of Controlling and } \\
\text { Logistics }\end{array}$ \\
\hline $\begin{array}{l}\text { Universität Bern } \\
\text { (CH) }\end{array}$ & $\begin{array}{l}\text { Chstitut für Unternehmensrechnung und } \text { Business Administration } \\
\text { Controlling }\end{array}$ & $\begin{array}{l}\text { Institute for Accounting and } \\
\text { Controlling }\end{array}$ \\
\hline $\begin{array}{l}\text { Universität } \\
\text { St.Gallen (CH) }\end{array}$ & $\begin{array}{l}\text { Institut für Accounting, Controlling und } \\
\text { Auditing, Lehrstuhl für Controlling / } \\
\text { Performance Management }\end{array}$ & $\begin{array}{l}\text { Institute of Accounting, Control } \\
\text { and Auditing, Chair of } \\
\text { Controlling / Performance } \\
\text { Management }\end{array}$ \\
\hline
\end{tabular}


At first glance, this scenario is unrealistic with these low figures. However, what is more interesting about German controlling is its use in practice (e.g. SAP CO [Controlling] Module). This means that many large German companies also enter the battle for German meaning of controlling. Not only they export the application, but they also call organizational units controlling units.

\subsection{Golden mean}

The second and third scenario may seem too radical in the short term. The fourth assumes a slight adjustment of the term of controlling to controllership. This scenario would ultimately lead again to the abandonment of the term to the favor of management. In fact, we already have some authors who meet this scenario. However, many German authors point out that controllership is the activity of the controller but does not describe the whole issue of (German) controlling. None of the 84 examined departments/chairs in Germanspeaking countries uses the term controllership in the English translation of their title.

\subsection{One future}

During the examination of this issue, we also found several views of German authors calling for unity. This would require a rapprochement of both theories and cooperation as both business economics and management. Ultimately, there would be a theory created that further combines the knowledge of both areas. The result of such an approximation is shown in a figure by Becker \& Heinzelmann [1, p.89], which displays controlling as the intersection of the manager's and controller's work when the manager manages the business and is responsible for the result and the controller has the economic withdrawal and is responsible for transparency of results.

What does such a future require? In any case, better communication between the supporters of both camps, which may also contain critic of the other. In the next step, cooperation with each other and the common workplace is the last important step.

In the names of German and associated chairs, we discovered 26 cases where their English name could symbolize the combination of two theories into one, as official translations combine management/managerial accounting and control. Without an in-depth study of publications and teaching, we cannot conclude whether they actually fulfill it. These chairs are part of the following universities: Technische Universität Berlin, Technische Universität Braunschweig, Universität Bremen, Technische Universität Chemnitz, Technische Universität Dortmund, Technische Universität Dresden, FriedrichAlexander Universität Erlangen-Nürnberg, Europa Universität Viadrina Frankfurt, GeorgAugust-Universität Göttingen, Helmut Schnidt Universität, Technische Universität Ilmenau, Otto Von Guericke Universität Magdeburg, Ludwig Maximilians Universität München (2), Oestrich-Winkel EBS Business School, Carl von Ossietzky Universität Oldenburg, Universität Rostock, Universität Siegen, Universität Stuttgart, Otto Beisheim School of Management (3), Uni Witten/Herdecke, Bergische Universität Wuppertal, KarlFranzens-Universität Graz (A), Universität Freiburg (CH).

We certainly admit that managers in large and medium-sized enterprises may exhibit cognitive limitations for processing the current amount of information, so controller's expert advice is appropriate when performing control function [Meyer].

\section{Conclusions}

In studying the issue, we have found that a major problem is that authors using this term do not have sufficient knowledge about the use of the term by others from another area. While German-speaking and associated CEE authors dealing with business economics have missed the use in management, English-using researchers in management have missed the use of the term in German business economics. More than 70 studied German publications 
do not mention that the term controlling is also used in a different meaning than the one described in the work and refers to the business economics. However, we cannot imagine the fact that all these authors have not found the meaning in management.

Often, in the arguments, we read in German works that there is a huge difference between the German verb "kontrollieren" and the English verb "to control" as the meaning of the second one is "to steer" or "to direct". However, how near is such a meaning to the phrase "to manage"? As mentioned at the beginning, this problem may really only concern a very small number of people involved. Yet, when one of the scenarios is fulfilled, it can go into really interesting dimensions.

From the point of view of management, we must really express the critic that literature in the field is inadequately researching the relationship between the manager and the controller. In addition, it also fails to mention the (increasing) use of the term controlling in German written literature.

For our own research, this issue is challenging as we operate in a region where the term controlling is predominantly used in the German meaning. This is in view of a) the teaching and research on universities; and b) practice of German companies that have made a significant contribution with their foreign investment in CEE markets. In the long run, we will see whether the meaning of the word will be adapted to the global management theory, or it will keep the semi-continental meaning. However, this will also very depend on the German authors who can make a significant contribution to fulfilling one of the presented scenarios, by directly pointing out in their publications that German controlling is not equivalent to English controlling.

As part of our research, we continue to explore the issue by gathering expert opinions on the issue through the ResearchGate scientific social network.

\section{References}

1. A. Becker, R. Heinzelmann, Management accounting und controlling: Ausbildungstraditionen in Großbritannien und im deutschsprachigen Raum [Management accounting and controlling: Teaching traditions in the UK and Germanspeaking countries]. In G. Seicht (Hrsg.). Jahrbuch für Controlling und Rechnungswesen 2013 [Yearbook for Controlling and Accounting 2013], 73-99. (LexisNexis Orac, Wien, 2013).

2. Ch. Binder, Die Entwicklung des Controllings als Teildisziplin der Betriebswirtschaftslehre [The development of controlling as a sub-discipline of business economics]. (Deutscher Universitäts-Verlag, Wiesbaden, 2006).

3. R.H. Chenhall, Management control systems design within its organizational context: findings from contingency-based research and directions for the future. Accounting, organizations and society, 28, 2-3, 127-168 (2003).

4. R.L. Daft, N.B. Macintosh, The nature and use of formal control systems for management control and strategy implementation. Journal of management, 10, 1, 4366 (1984).

5. C. Ebeling, Erfolgsfaktoren einer wertorientierten Unternehmensführung [Success factors of a value-oriented management]. (Deutscher Universitäts-Verlag, Wiesbaden, 2006).

6. C.R. Emmanuel, D.T. Otley, K.A. Merchant, Accounting for Management Control. $\left(2^{\text {nd }}\right.$ ed.). (Springer, London, 2013).

7. Ch. Endenich, Comparative Management Accounting. (Gabler, Wiesbaden, 2012).

8. E.S.L. Goodwin, A Further Sally on "Control". Michigan Business Review, 13, 9-18 (1960). 
9. E.S.L. Goodwin, Control: A Brief Excursion on the Meaning of a Word. Michigan Business Review, 12, 13-28 (1960).

10. S.G. Green, M.A. Welsh, Cybernetics and dependence: Reframing the control concept. Academy of Management Review, 13 , 2, 287-301 (1988).

11. P. Horvath, What is "German controlling"? Journal of cost management, 23, 2, 16-19 (2009)

12. H. Jung, Allgemeine Betriebswirtschaftslehre [General business studies] (12 $\left.2^{\text {th }} \mathrm{ed}.\right)$. (Oldenbourgh, München, 2010).

13. H. Koontz, C. O'Donnell, Principles of Management: An Analysis of Managerial Functions. (McGraw-Hill, New York, 1955).

14. U. Kück, Schnelleinstieg Controlling [Quick Start Controlling] (3 ${ }^{\text {rd }}$ ed.). (Rudolf Haufe, München, 2009).

15. J. Link, Führungssysteme: Strategische Herausforderung für Organisation, Controlling und Personalwesen [Management Systems: Strategic Challenge for Organization, Controlling and Human Resources]. ( $6^{\text {th }}$ ed.). (Vahlen, München, 2011)

16. R. Luther, T.C. Jones, A. Saxl, Experiencing Change in German Controlling: Management Accounting in a Globalizing World. (CIMA Publishing, Burlington, 2010).

17. M. Meyer, Controlling und begrenzte kognitive Fähigkeiten: Ausgangspunkte und Grundfragen [Controlling and limited cognitive abilities: starting points and basic questions]. In M. Meyer, J. Weber (Hrsg.). Controlling und begrenzte kognitive Fähigkeiten [Controlling and limited cognitive skills]. (Gabler, Wiesbaden, 2011).

18. Merchant, K.A. The control function of management. Sloan management review, 23, 4, 43-55 (1982)

19. T. Reichmann, Controlling. Concepts of Management Control, Controllership, and Ratios. (Springer, Berlin, 1997).

20. U. Schäffer, Management accounting research in Germany: From splendid isolation to being part of the international community. Journal of Management Control, 23, 4, 291 309 (2013)

21. R. Schwarz, Controlling Systeme. Eine Einführung in Grundlagen, Komponenten und Methoden des Controlling [Controlling systems. An introduction to the basics, components and methods of controlling]. (Gabler, Wiesbaden, 2002).

22. K. Stoffel, Controllership im internationalen Vergleich [Controllership in international comparison]. (Gabler, Wiesbaden, 1995)

23. T.R. Tyler, S.L. Blader, Can Business Effectively Regulate Employee Conduct? The Antecedents of Rule Following in Work Settings. Academy of Management Journal 48, 6, 1143-1158 (2005).

24. L.F. Urwick, The meaning of control. Michigan Business Review, 12, 5, 9-13 (1960).

25. WHU - Otto Beisheim School of Management, Chairs - WHU - Otto Beisheim School of Management. (2020) https://www.whu.edu/en/faculty-research/managementgroup/institute-of-management-accounting-and-control/students/links/chairs/. 